\title{
ANALISIS FAKTOR-FAKTOR DOMINAN YANG MEMPENGARUHI EKONOMI RUMAHTANGGA PETANI PADI SAWAH DI KECAMATAN SUNGAI MANDAU KABUPATEN SIAK
}

\author{
The Analysis of Dominant Factors that Respect to Household Economic of Paddy Farmers in \\ Sungai Mandau Sub District Siak Municipality
}

\author{
Suci Jamilah, Suardi Tarumun dan Djaimi Bakce \\ Program Studi Agribisnis, Jurusan Agribisnis, Fakultas Pertanian, Universitas Riau \\ Email: suci.jamilah.ur@gmail.com \\ [Diterima Desember 2017;Disetujui Maret 2018]
}

\begin{abstract}
This research aims to analyze the dominant factors that respect to household economics of paddy farmers that included production, allocation of work time, income, and expenditure in Sungai Mandau Sub-district, Siak Municipality. The econometric approach using a model of simultaneous equations with Two-Stage Least Square method (2SLS) was used to answer the research goals. The main finding of this research showed that the dominant factors that respect to production are harvest area of paddy and costs of production facilities. Allocation of work time consists of: First, allocation of work time on farming respects the allocation of work time of off-farm and labor force. Second, the hired labor respects to farming income. Third, allocation of work time of off-farm respects to offfarm income, allocation of work time on farming, farmer's work experiences and age of farmers. Income respects to the allocation of work time of off-farm. Expenditure consists of: First, food consumption respects to total income, the number of families, and health spending. Second, non-food consumption respects to total income. Third, education investment respects to total income and the number of school children. Fourth, paddy farming investment respects to total income, harvest area of paddy, and food consumption. Fifth, saving respects to total income, total consumption, education investment, and health spending.
\end{abstract}

Keywords: Allocation of work time, Income, expenditure, Paddy

\begin{abstract}
ABSTRAK
Penelitian ini bertujuan untuk menganalisis faktor-faktor dominan yang mempengaruhi ekonomi rumahtangga petani padi sawah yang meliputi produksi, alokasi waktu kerja, pendapatan dan pengeluaran di Kecamatan Sungai Mandau Kabupaten Siak. Untuk menjawab tujuan penelitian ini digunakan pendekatan ekonometrik dengan metode Two Stage Least Square (2 SLS). Temuan utama dari penelitian adalah: faktor-faktor dominan yang mempengaruhi aspek produksi adalah luas panen padi sawah dan biaya sarana produksi. Aspek alokasi waktu kerja meliputi: Pertama, alokasi waktu kerja dalam usahatani padi sawah dipengaruhi alokasi waktu kerja luar usahatani padi dan angkatan kerja rumahtanga. Kedua, penggunaan tanaga kerja luar keluarga dipengaruhi pendapatan di dalam usahtani padi sawah.Ketiga, alokasi waktu kerja luar usahatani padi sawah dipengaruhi pendapatan di luar usahatani padi sawah, alokasi kerja dalam usahatani padi sawah, pengalaman kerja petani dan umur petani.Aspek pendapatan di luar usahatani padi sawah dipengaruhi alokasi waktu kerja luar usahatani padi sawah. Aspek pengeluaran meliputi: Pertama, pengeluaran konsumsi pangan dipengaruhi oleh pendapatan total, jumlah anggota keluarga dan pengeluaran kesehatan. Kedua, pengeluaran konsumsi non pangan dipengaruhi pendapatan total.Ketiga, investasi pendidikan dipengaruhi pendapatan total dan jumlah anak sekolah.Keempat, investasi pada usahatani padi sawah dipengaruhi pendapatan total, luas panen padi sawah dan konsumsi pangan.Kelima, pengeluaran rekreasi dipengaruhipendapatan total, konsumsi total, investasi pendidikan dan tabungan.Keenam, tabungan dipengaruhi pendapatan total, konsumsi total, investasi pendidikan dan pengeluaran kesehatan.
\end{abstract}

Kata Kunci: Waktu Kerja, Pendapatan, Pengeluaran, Padi Sawah. 


\section{PENDAHULUAN}

Beras merupakan bahan pangan pokok bagi penduduk Indonesia yang memberikan energi dan zat gizi yang tinggi.Beras telah menjadi komoditas strategis dalam kehidupan bernegara di Indonesia.Peran beras, selain sebagai sumber pangan pokok juga menjadi sumber penghasilan bagi petani dan kebutuhan hidup sehari-hari bagi jutaan penduduk.Meskipun pemerintah telah mengupayakan diversifikasi pangan, namun sampai saat ini belum mampu mengubah preferensi penduduk terhadap bahan pangan beras.Oleh karena itu ketersediaan beras harus selalu terjaga, berkelanjutan, bahkan harus ditingkatkan (Kementrian Pertanian, 2015).

Indonesia masih menghadapi beberapa kendala dalam hal penyediaan beras domestik, khususnya yang berkaitan dengan terbatasnya kapasitas produksi nasional yang disebabkan antara lai oleh: (a) konversi lahan pertanian ke non pertanian; (b) menurunnya kualitas dan kesuburan tanah akibat degradasi lingkungan dan kerusakan daerah aliran sungai (DAS); (c) makin terbatas dan tidak pastinya ketersediaan air irigasi untuk mendukung kegiatan usahatani padi akibat perubahan iklim mikro dan persaingan pemanfaatan sumber daya air dengan sektor permukiman dan industri; (d) kurangnya pemeliharaan jaringan irigasi; (e) makin tidak pastinya pola hujan akibat perubahan iklim global (Suryana, dkk., 2001).

Hal tersebut juga terjadi di Provinsi Riau. Produksi beras di Provinsi Riau mengalami penurunan terlihat dari jumlah produksi pada dua tahun terakhir yaitu pada tahun 2014 produksi beras hanya sebesar 245.625 ton, yang sebelumnya pada tahun 2013 produksi beras lebih tinggi yakni sebesar 276.138 ton. Produksi yang menurun akhirnya tidak mampu mengimbangi tingginya permintaan beras nasional yang diiringi dengan terus bertambahnya jumlah penduduk di Provinsi Riau setiap tahunnya (Badan Ketahanan Pangan Provinsi Riau, 2015).

Salah satu kabupaten penghasil beras di Provinsi Riau adalah Kabupaten Siak.Kabupaten Siak mempunyai sumberdaya alam yang besar dengan tingkat pertumbuhan penduduk yang cukup tinggi.Kecamatan Sungai Mandau merupakan kecamatan ketiga terbesar di Kabupaten Siak setelah Kecamatan Bunga
Raya dan Sabak Auh.Produksi padi sawah di Kecamatan Sungai Mandau sebesar 5.776,80 ton (Badan Pusat Statistik Kabupaten Siak, 2015).

Petani padi sawah tidak menjadikan usahtani padi sebagai satu-satunya sumber pencarian. Hal ini disebabkan karena terjadinya penurunan produksi yang kemudian akan menurunkan penerimaan dari usahatani padi. Untuk terus dapat memenuhi kebutuhan rumahtangga, maka rumahtangga petani mencari pendapatan diluar usahatani padi dengan mengalokasikan waktu kerjanya di luar usahatani padi.

Becker (1965) mengembangkan teori yang mempelajari tentang perilaku rumahtangga dan merupakan dasar dari Ekonomi Rumahtangga Baru (New Household Economics).Rumahtangga dipandang sebagai pengambil keputusan dalam kegiatan produksi dan konsumsi, serta hubungan alokasi waktu dan pendapatan rumahtangga yang dianalisis secara simultan. Formulasi ini menyatakan bahwa terdapat dua proses dalam perilaku rumahtangga, yakni proses produksi yang digambarkan oleh fungsi produksi dan proses konsumsi untuk memilih barang dan waktu santai. Hal yang serupa juga dikemukan oleh Chang (2012) bahwa rumahtangga pertanian dicirikan dengan peran ganda dalam memproduksi output dan mengkoordinasikan konsumsi dari anggota rumahtangganya melalui alokasi waktu antara bekerja, baik on-farm dan atau off-farm serta waktu santai (leisure).

Petani berperan dalam pengambilan keputusan produksi yang secara langsung akan berpengaruh terhadap jumlah pendapatan yang akan diterima sedangkan tingkat pendapatan yang diterima akan berpengaruh terhadap keputusan konsumsi rumahtangga petani karena besarnya konsumsi rumahtangga tergantung dari besarnya pendapatan dan tingkat harga. Akibatnya dengan tingkat pendapatan dari usahatani yang rendah akan mendorong anggota rumahtangga petani untuk mencari cara agar dapat memperoleh tambahan pendapatan dalam rangka menjamin kesejahteraan anggota rumahtangganya serta untuk memenuhi kebutuhan pengeluaran rumahtangganya, baik untuk konsumsi pangan maupun non pangan (Makki, 2014). Kondisi di daerah penelitian, hal ini diwujudkan dalam bentuk alokasi kerja anggota rumahtangga petani padi pada kegiatan 
yang menghasilkan tambahan pendapatan, khususnya kegiatan di luar usahatani dan di luar sektor pertanian.

Berdasarkan uraian di atas penting dilakukan pengkajian mengenai model pengambilan keputusan rumahtangga petani yang didasarkan pada hubungan antara produksi, alokasi waktu kerja, pendapatan dan pengeluaran petani padi sawah di Kecamatan Sungai Mandau Kabupaten Siak dalam rangka untuk menjamin kesejahteraan anggota rumahtangganya.

Secara umum, penelitian ini bertujuan untuk membangun model ekonomi rumahtangga petani padi sawah di Kecamatan Sungai Mandau Kabupaten Siak.Secara khusus tujuan penelitian ini adalah untuk menganalisis faktor-faktor yang mempengaruhi ekonomi rumahtangga petani padi sawah yang dilihat dari 4 aspek yaitu produksi, alokasi waktu kerja, pendapatan dan pengeluaran.

\section{METODE PENELITIAN Waktu dan Lokasi Penelitian}

Penelitian dilaksanakan mulai September sampai Oktober 2016.Lokasi penelitian di Kecamatan Sungai Mandau, Kabupaten Siak.Penentuan lokasi dilakukan secara sengaja dengan pertimbangan bahwa daerah ini memilikii luas tanaman padi yang cukup luas di Kabupaten Siak.

\section{Teknik Pengambilan Sampel}

Populasi dalam penelitian ini adalah rumahtangga petani padi sawah di Kecamatan Sungai Mandau.Pengambilan wilayah dilakukan dengan menggunakan metode Multistage Sampling. Kabupaten Siak merupakan kabupaten dengan total produksi terbesar kelima. Kecamatan Sungai Mandau merupakan kecamatan dengan produksi terbesar ketiga setelah Kecamatan Bunga Raya dan Kecamatan Sabak Auh.Selanjutnya pemilihan desa dengan kriteria produksi terbesar pertama, kedua dan ketiga secara berturut-turut adalah Desa Muara Kelantan, Desa Muara Bungkal dan Desa Lubuk Jering.

Sampel diambil 15 petani setiap desa, pengambilan sampel menggunakan metode Accidential Sampling dengan mewawancarai petani padi sawah yang jumpai pada saat penelitian.Dengan demikian jumlah sampel pada penelitian ini sebanyak 45 sampel Menurut Pasaribu (1981) untuk ukuran sampel besar dengan populasi yang tidak diketahui pasti jumlahnya, pengambilan sampel besar atau sama dengan $30(\mathrm{~N} \geq 30)$ secara statistik sudah mempunyai distribusi yang normal. Oleh karena itu pengambilan sampel sebanyak 45 sudah mewakili populasi.

Data yang digunakan adalah data primer dengan mewawancarai langsung petani padi sawah di Kecamatan Sungai Mandau Kabupeten Siak.

\section{TAHAPAN ANALISIS DATA}

\section{1) Spesifikasi Model}

Tahapan pertama dan sangat penting dalam penelitian dengan pendekatan ekonometrika adalah spesifikasi model.Pada tahapan ini dapat digambarkan hubungan antara peubah-peubah yang dimasukkan ke dalam model, kemudian diformulasikan dalam sejumlah persamaan struktural dan identitas (Koutsoyiannis, 1977).

Spesifikasi model yang dirumuskan pada penelitian ini diformulasikan 17 persamaan, yang terdiri dari 11 persamaan struktural dan 6 persamaan identitas yang diuraikan dalam 4 aspek aktivitas ekonomi rumahtangga sebagai berikut:

\section{Aspek produksi:}

Produksi gabah kering giling yang dihasilkan rumahtangga petani padi sawah diduga dipengaruhi oleh luas panen padi sawah, total tenaga kerja dalam usaha dan biaya sarana produksi.

Persamaan produksi gabah kering giling dirumuskan sebagai berikut:

$\mathrm{Qi}=\mathrm{a}_{0}+\mathrm{a}_{1}$ LPPS $_{\mathrm{i}}+\mathrm{a}_{2} \mathrm{TTKU}_{\mathrm{i}}+$

$$
a_{3} B P_{i}+U_{1 i} \ldots \ldots \ldots \ldots \ldots \ldots \ldots \ldots \ldots . . .(1)
$$

dimana:

Q =Produksi Gabah Kering Giling (Kg/Luas Panen/Tahun)

TTKU $=$ Total Tenaga Kerja dalam Usaha (HOK/Tahun)

$\mathrm{BSP}=$ Biaya Sarana Produksi (Rp/tahun)

\section{Aspek Alokasi Waktu Kerja}

Alokasi tenaga kerja keluarga rumahtanggga petani padi sawah terdiri dari alokasi tenaga kerja keluarga dalam dan luar usahatani padi. Dalam aktivitas produksinya, rumahtangga petani padi sawah juga 
akanmenggunakan tenaga kerja dari luar keluarga apabila tenaga kerja kelluraga tidak dapat melakukan aktivitas tersebut secara penuh.

Persamaan pada alokasi waktu kerja dan penggunaan tenaga kerja ini dirumuskan sebagai berikut:

$$
\begin{aligned}
& \mathrm{CKDU}_{\mathrm{i}}=\mathrm{b}_{0}+\mathrm{b}_{1} \mathrm{PPD}_{\mathrm{i}}+\mathrm{b}_{2} \mathrm{CKLU}_{\mathrm{i}}+ \\
& b_{3} A K P_{i}+b_{4} U P_{i}+U_{2 i} \ldots \ldots . .(2) \\
& \mathrm{TKLP}_{\mathrm{i}}=\mathrm{c}_{0}+\mathrm{c}_{1} \mathrm{PPD}_{\mathrm{i}}+\mathrm{c}_{2} \mathrm{UP}_{\mathrm{i}}+\mathrm{U}_{3 \mathrm{i}}(3) \\
& \mathrm{CKLU}_{\mathrm{i}}=\mathrm{d}_{0}+\mathrm{d}_{1} \mathrm{PPLU}_{\mathrm{i}}+\mathrm{d}_{2} \mathrm{CKDU}_{\mathrm{i}}+ \\
& \mathrm{d}_{3} P K P_{\mathrm{i}}+\mathrm{d}_{4} \mathrm{UP}_{\mathrm{i}}+\mathrm{U}_{4 \mathrm{i}} \ldots \ldots \text { (4) } \\
& \mathrm{TTKU}_{\mathrm{i}}=\mathrm{CKDU}_{\mathrm{i}}+\mathrm{TKLP}_{\mathrm{i}} \\
& \mathrm{TCKP}_{\mathrm{i}}=\mathrm{CKDU}_{\mathrm{i}}+C K L U_{i}
\end{aligned}
$$

$\mathrm{CKDU}_{\mathrm{i}}=$ Alokasi Kerja Keluarga Petani dalam Usahatani Padi Sawah (HOK/Tahun)

$\mathrm{PPD}_{\mathrm{i}} \quad=$ Pendapatan Rumahtangga Petani dalam Usahatani Padi Sawah (Rp/Tahun)

$\mathrm{CKLU}_{\mathrm{i}}=$ Alokasi Waktu Kerja Keluarga di Luar Usahatani Padi Sawah (HOK/Tahun)

$\mathrm{AKP}_{\mathrm{i}}=$ Angkatan Kerja Rumahtangga Petani Padi Sawah (Orang)

$\mathrm{UP}_{\mathrm{i}} \quad=$ Umur petani (Tahun)

TKLP $_{i}=$ Tenaga Kerja Luar Keluarga (HOK/Tahun)

$\mathrm{CKLU}_{\mathrm{i}}=$ Alokasi Kerja Keluarga di Luar Usahatani Padi Sawah (HOK/Tahun)

PPLU $_{\mathrm{i}}=$ Pendapatan Rumahtangga di Luar Usahatani Padi Sawah (Rp/Tahun)

$\mathrm{PKP}_{\mathrm{i}} \quad=$ Pengalaman Kerja Petani (Tahun)

$\mathrm{TTKU}_{\mathrm{i}}=$ Total Penggunaan Tenaga Kerja dalam Usahatani Padi Sawah (HOK/Tahun)

TCKP $_{\mathrm{i}}=$ Total Alokasi Kerja Rumahtangga Petani Padi Sawah (HOK/Tahun)

\section{Aspek Pendapatan}

Pendapatan rumahtangga petani padi sawa terdiri dari pendapatan dalam usaha dan pendapatan di luar usahatani padi. Pendapatan dalam usahatani padi adalah penerimaan bersih yang diperoleh, yaitu penerimaan kotor dari hasil usaha dikurangi total biaya usaha.

Persamaan pada aspek pendapatan ini dirumuskan sebagai berikut:

$\mathrm{PPD}_{\mathrm{i}}=\left(\mathrm{Pq}_{\mathrm{i}} * \mathrm{Q}_{\mathrm{i}}\right)-\mathrm{TBU}_{\mathrm{i}}$

$\mathrm{TBU}_{\mathrm{i}}=\mathrm{UG}_{\mathrm{i}}+\mathrm{BSP}_{\mathrm{i}}$

$$
\begin{aligned}
& \operatorname{PPLU}_{\mathrm{i}}=\mathrm{e}_{0}+\mathrm{e}_{1} \mathrm{CKLU}_{\mathrm{i}}+\mathrm{e}_{2} \mathrm{AKP}_{\mathrm{i}}+\mathrm{U}_{5 \mathrm{i} \cdot} \text { (9) } \\
& \mathrm{PTP}_{\mathrm{i}}=\mathrm{PPD}_{\mathrm{i}}+\mathrm{PPLU}_{\mathrm{i}} \\
& \text { Dimana: } \\
& \mathrm{TBU}_{\mathrm{i}}=\text { Total Biaya Usahatani Padi Sawah } \\
& \text { (Rp/Tahun) } \\
& \mathrm{Pq}_{\mathrm{i}}=\text { Harga Gabah Kering Giling } \\
& (\mathrm{Rp} / \mathrm{Kg}) \\
& \mathrm{Q}_{\mathrm{i}} \quad=\text { Produksi Gabah Kering Giling } \\
& \text { (Kg/Tahun) } \\
& \mathrm{UG}_{\mathrm{i}} \quad=\text { Upah/Gaji (Rp/Tahun) } \\
& \mathrm{PTP}_{\mathrm{i}}=\text { Pendapatan Total Rumahtangga } \\
& \text { Petani Padi Sawah (Rp/Tahun) }
\end{aligned}
$$

\section{Aspek pengeluaran:}

Pengeluaran rumahtangga petani padi sawah dikelompokkan menjadi: pengeluaran pangan, non pangan, nvestasi pendidikan, investasi usaha, rekreasi dan menabung. Pengeluaran pangan dan non pangan disebut dengan pengeluaran konsumsi, dengan menjumlahkan keduanya akan diperoleh konsumsi total. Persamaan ada aspek pengeluaran ini dirumuskan sebagai berikut: $\mathrm{KPP}_{\mathrm{i}}=\mathrm{f}_{0}+\mathrm{f}_{1} \mathrm{PTP}_{\mathrm{i}}+\mathrm{f}_{2} \mathrm{JANP}_{\mathrm{i}}+\mathrm{f}_{3} \mathrm{KK}_{\mathrm{i}}+$

$$
\mathrm{U}_{6 \mathrm{i}} \text {.................................... (11) }
$$

$\mathrm{KNPP}_{\mathrm{i}}=\mathrm{g}_{0}+\mathrm{g}_{1} \mathrm{PTP}_{\mathrm{i}}+\mathrm{g}_{2} \mathrm{KK}_{\mathrm{i}}+\mathrm{U}_{7 \mathrm{i}}(12)$

$\mathrm{KTP}_{\mathrm{i}}=\mathrm{KPP}_{\mathrm{i}}+\mathrm{KNPP}_{\mathrm{i}}$

IEP $_{\mathrm{i}}=\mathrm{h}_{0}+\mathrm{h}_{1} \mathrm{PTP}_{\mathrm{i}}+\mathrm{h}_{2} \mathrm{JASP}_{\mathrm{i}}+\mathrm{U}_{8 \mathrm{i}}(14)$

IUP $_{\mathrm{i}}=\mathrm{i}_{0}+\mathrm{i}_{1}$ PTP $_{\mathrm{i}}+\mathrm{i}_{2}$ LPPS $_{\mathrm{i}}+\mathrm{i}_{3} \mathrm{KPP}_{\mathrm{i}}+$

$\mathrm{U}_{9 \mathrm{i}}$

$\mathrm{KRP}_{\mathrm{i}}=\mathrm{j}_{0}+\mathrm{j}_{1} \mathrm{PTP}+\mathrm{j}_{2} \mathrm{KTP}_{\mathrm{i}}+\mathrm{j}_{3}$ IEP +

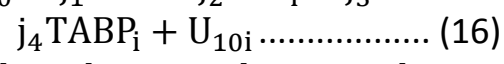

$\mathrm{TABP}_{\mathrm{i}}=\mathrm{k}_{0}+\mathrm{k}_{1} \mathrm{PTP}_{\mathrm{i}}+\mathrm{k}_{2} \mathrm{KTP}_{\mathrm{i}}+\mathrm{k}_{3} \mathrm{IEP}_{\mathrm{i}}+$ $\mathrm{k}_{4} \mathrm{KK}_{\mathrm{i}}+\mathrm{U}_{1 \mathrm{l}}$

Dimana:

$\mathrm{KPP}_{\mathrm{i}}=$ Konsumsi Pangan Rumahtangga Petani Padi Sawah (Rp/Tahun)

$\mathrm{KNPP}_{\mathrm{i}}=$ Konsumsi Non Pangan Rumahtangga Petani Padi Sawah (Rp/Tahun)

$\mathrm{JANP}_{\mathrm{i}}=$ Jumlah Anggota Keluarga Rumahtangga Petani Padi Sawah (Orang)

$\mathrm{KK}_{\mathrm{i}}=$ Pengeluaran Kesehatan Rumahtangga Petani Padi Sawah (Rp/Tahun)

$\mathrm{KTP}_{\mathrm{i}}=$ Konsumsi Total Rumahtangga Petani Padi Sawah (Rp/Tahun)

$\mathrm{IEP}_{\mathrm{i}}=$ Investasi Pendidikan Rumahtangga Petani Padi Sawah (Rp/Tahun)

$=$..uJumlahRumahtangga Petani Padi (Orang) 

$\mathrm{IUP}_{\mathrm{i}}=$ Investasi pada Usahatani Padi Sawah (Rp/Tahun)
$\mathrm{KRPi}=$ Pengeluaran Rekreasi Rumahtangga Petani Padi Sawah (Rp/Tahun)

$\mathrm{TABP}_{\mathrm{i}} \quad=$ Tabungan Petani $(\mathrm{Rp} /$ Tahun $)$.
$\mathrm{JASP}_{\mathrm{i}}=$ Jumlah Anak Sekolah Rumahtangga Petani Padi (Orang)

Simplifikasi model ekonomi rumahtangga petani padi sawah di Kecamatan Sungai Mandau Kabupaten Siak dapat dilihat pada Gambar 1.

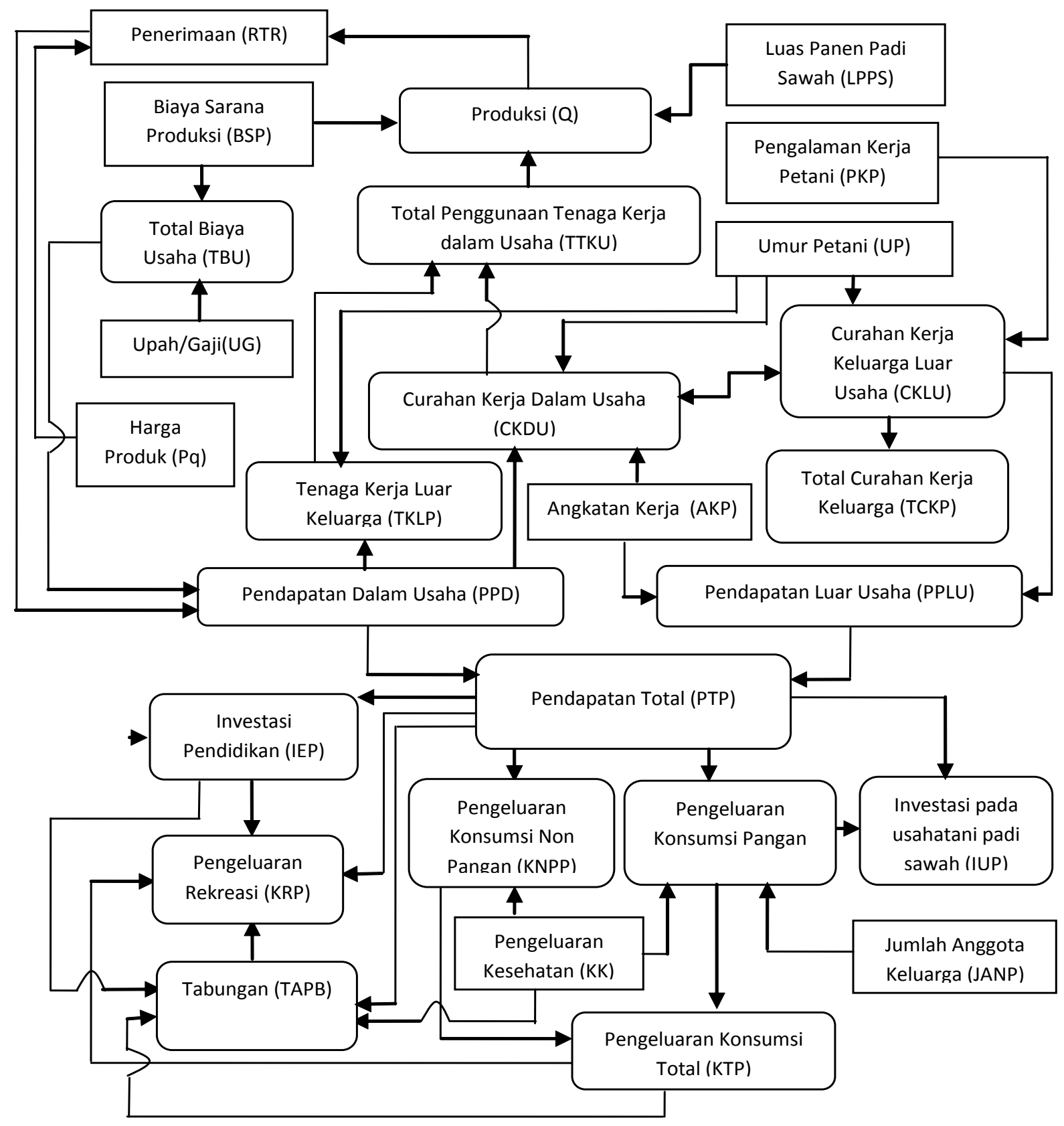

Keterangan: $\square=$ peubah endogen $\square=$ peubah eksogen

Gambar 1. Simplifikasi Ekonomi Rumahtangga Petani Padi Sawah Kecamatan Sungai Mandau Kabupaten Siak 


\section{2) Identifikasi Model}

Rumus identifikasi model berdasarkan order condition adalah sebagai berikut (Gujarati, 2011; Pindyck and Rubinfield, 2000; Intriligator, 1978; Koutsoyiannis, 1977):

$(\mathrm{K}-\mathrm{M}) \geq(\mathrm{G}-1)$

dimana:

$\mathrm{K}=$ Total peubah dalam model (peubah endogen dan peubah determinan)

$\mathrm{M}$ = Jumlah peubah endogen dan eksogen yang dimasukkn kedalam suatu persamaan tertentu dalam model.
$\mathrm{G}=$ Total persamaan (jumlah peubah endogen)

Jika $(\mathrm{K}-\mathrm{M})>(\mathrm{G}-1)$, maka persamaan overidentified; jika $(\mathrm{K}-\mathrm{M})=(\mathrm{G}-1)$, maka persamaan exactly identified; dan jika (K-M) < (G-1), maka persamaan unidentified (Koutsoyiannis, 1977; Intriligator, 1978). Hasil identifikasi model ekonomi rumahtangga petani padi sawah dapat dilihat pada Tabel 1.

Tabel 1. Hasil Identifikasi Model Ekonomi Rumahtangga Petani Padi Sawah di Kecamatan Sungai Mandau Kabupaten Siak.

\begin{tabular}{|c|c|c|c|c|c|}
\hline No. & Nama Persamaan & M & $\mathrm{K}-\mathrm{M}$ & G-1 & Kesimpulan \\
\hline 1. & Produksi gabah kering giling & 3 & 25 & 16 & over identified \\
\hline 2. & Tenaga kerja luar keluarga & 4 & 24 & 16 & over identified \\
\hline 3. & $\begin{array}{l}\text { Alokasi kerja rumahtangga dalam usahatani } \\
\text { padi sawah }\end{array}$ & 2 & 26 & 16 & over identified \\
\hline 4. & 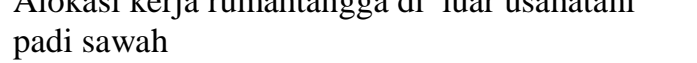 & 4 & 24 & 16 & over identified \\
\hline 5. & Pendapatan luar usahatani padi sawah & 2 & 26 & 16 & over identified \\
\hline 6. & Pengeluaran konsumsi pangan rumahtangga & 3 & 25 & 16 & over identified \\
\hline 7. & Pengeluaran konsumsi non pangan rumahtangga & 2 & 26 & 16 & over identified \\
\hline 8. & Investasi pendidikan & 2 & 26 & 16 & over identified \\
\hline 9. & Investasi pada usahatani padi sawah & 3 & 25 & 16 & over identified \\
\hline 10. & Pengeluaran rekreasi rumahtangga & 4 & 24 & 16 & over identified \\
\hline 11. & Tabungan & 4 & 24 & 16 & over identified \\
\hline
\end{tabular}

Tabel 1 dapat diterangkan bahwa berdasarkan kriteria order condition setiap persamaan struktural dalam model ekonomi rumahtangga petani padi sawah adalah overidentified atau teridentifikasi berlebih, maka metode estimasi yang paling sesuai digunakan adalah Two Stage Least Square (2SLS).

Berdasarkan hasil identifikasi tersebut, metode estimasi yang sesuai digunakan adalah Two Stage Least Square (2SLS) menggunakan taraf nyata dengan toleransi sampai 20 persen $(\alpha=20 \%)$.

\section{3) Perhitungan Elastisitas}

Konsep elastisitas digunakan untuk mendapatkan nilai kuantitatif dari respon suatu fungsi terhadap faktor-faktor yang mempengaruhi persamaan. Dari hasil pendugaan model yang diperoleh, maka dihitung elastisitas variabel-variabel yang memiliki nilai dugaan yang berbeda nyata sama dengan nol pada taraf sampai dengan 20 persen.

Hal ini untuk melihat apakah peubahpeubah yang mempengaruhi pada model berpengaruh secara positif atau negatif dan apakah peubah-peubah yang mempengaruhi pada model bersifat responsif atau tidak terhadap peubah yang dipengaruhinya. Jika nilai elastisitas yang diperoleh besar dari 1 maka peubah yang dipengaruhi bersifat responsif terhadap perubahan peubah yang mempengaruhinya, tetapi jika nilai elastisitas yang diperoleh kecil dari 1 maka peubah yang dipengaruhi bersifat tidak responsif terhadap perubahan peubah yang mempengaruhinya. Untuk menghitung nilai elastisitas dapat dirumuskan sebagai berikut :

$$
\mathrm{E} \quad=\frac{\partial Y}{\partial X}+\frac{\bar{X}}{\bar{Y}}=b \frac{\bar{X}}{\bar{Y}}
$$


Dimana:

$\mathrm{E}=$ Elastisitas

$\mathrm{b}=$ Parameter dugaan dari peubah eksogen

$\bar{X}=$ Rata-rata peubah eksogen

$\bar{Y}=$ Rata-rata peubah endogen (Mean Predicted ha sil validasi model)

\section{HASIL DAN PEMBAHASAN}

Berdasarkan pendugaan model keputusan ekonomi rumahtangga memiliki nilai koefisien determinasi $\left(\mathrm{R}^{2}\right)$ dari setiap model persamaan. Nilai koefisien determinasi pada model keputusan ekonomi rumahtnggga petani padi sawah berkisar antara 0,53223 sampai 0,98939 dengan nilai statistik uji $\mathrm{F}$ berkisar antara 22,49 sampai 932,61 yang berbeda nyata dengan nol pada taraf 1 persen. Hasil model ekonomi rumahtanggga petani padi sawah dapat dilihat pada Tabel 2.

Tabel 2. Hasil Pendugaan Model Ekonomi Rumahtangga Petani Padi Sawah

\begin{tabular}{|c|c|c|c|c|c|}
\hline Peubah & Label & $\begin{array}{l}\text { Parameter } \\
\text { Dugaan }\end{array}$ & t-hitung & Prob $>$ ltl & Elastisitas \\
\hline \multicolumn{6}{|l|}{ A. Aspek Produksi } \\
\hline 1. Produksi GKG & Q & & & & \\
\hline Intercept & $\mathrm{a} 0$ & 1326,43 & 4,34 & $<.0001$ & \\
\hline Luas Panen Padi Sawah & LPPS & 1200,385 & 6,71 & $<.0001$ & 0,407468 \\
\hline Total tenaga kerja dalam usaha & TTKU & 0,60531 & 0,92 & 0,3649 & \\
\hline Biaya sarana produksi & BSP & 0,000319 & 2,28 & 0,0276 & 0,245223 \\
\hline $\mathrm{R}^{2}=0,91851$ & Fvalue $=154,0$ & & & $\operatorname{Pr}>\mathrm{F}=$ & \\
\hline \multicolumn{6}{|l|}{ B. Aspek Alokasi Kerja } \\
\hline $\begin{array}{l}\text { 2. Alokasi Kerja Keluarga di Dalam } \\
\text { Usaha }\end{array}$ & CKDU & & & & \\
\hline Intercept & $\mathrm{a} 0$ & 693,0308 & 4,63 & $<.0001$ & \\
\hline Pendapatan di dalam usaha & PPD & $2,94 \mathrm{E}-06$ & 1,22 & 0,2293 & \\
\hline Alokasi kerja di luar usaha & CKLU & $-2,17367$ & $-6,34$ & $<.0001$ & $-0,72538$ \\
\hline Angkatan kerja rumahtangga & $\mathrm{AKP}$ & 36,86718 & 2,77 & 0,0084 & 0,218569 \\
\hline Umur petani & UP & $-1,61946$ & -1 & 0,3248 & \\
\hline $\mathrm{R}^{2}=0,83576$ & Fvalue $=50,89$ & & & $\mathrm{Pr}>\mathrm{F}=$ & \\
\hline $\begin{array}{l}\text { 3. Penggunaan tenaga kerja luar } \\
\text { keluarga petani }\end{array}$ & TKLP & & & & \\
\hline Intercept & $\mathrm{a} 0$ & $-7,95016$ & $-2,17$ & 0,0358 & \\
\hline Pendapatan di dalam usaha & PPD & $1,39 \mathrm{E}-06$ & 9,15 & $<.0001$ & 1,23828 \\
\hline Umur petani & UP & 0,05159 & 0,61 & 0,5432 & \\
\hline $\mathrm{R}^{2}=0,76532$ & Fvalue $=68,48$ & & & $\operatorname{Pr}>\mathrm{F}=$ & \\
\hline 4. Alokasi Kerja di Luar Usaha & CKLU & & & & \\
\hline Intercept & $\mathrm{a} 0$ & 152,9258 & 2,21 & 0,0331 & \\
\hline Pendapatan di luar usaha & PPLU & $5,21 \mathrm{E}-06$ & 2,95 & 0,0053 & 0,604376 \\
\hline Alokasi kerja dalam usaha & CKDU & $-0,14431$ & $-2,31$ & 0,0262 & $-0,43254$ \\
\hline Pengalaman kerja petani & PKP & 0,663621 & 2 & 0,0524 & 0,118977 \\
\hline Umur petani & UP & $-0,92608$ & $-1,83$ & 0,0751 & $-0,32718$ \\
\hline $\mathrm{R}^{2}=0,90352$ & Fvalue $=93,65$ & & & $\operatorname{Pr}>\mathrm{F}=$ & \\
\hline $\begin{array}{l}\text { 5. TTKU = CKDU }+ \\
\text { TKLP }\end{array}$ & $\begin{array}{l}\mathrm{U}=\text { Total Alok } \\
\text { dalam Usaha }\end{array}$ & si Kerja & & & \\
\hline $\begin{array}{l}\text { 6. TCKP = CKDU+ } \\
\text { CKLU }\end{array}$ & Total Alokasi K & erja Petani & & & \\
\hline 7. $\mathrm{PPD}=\mathrm{TR}-\mathrm{TBU}$ & dapatan dalam & Usahatani, & $\mathrm{TR}=$ & $\begin{array}{r}\text { otal Revenu } \\
\text { Biaya }\end{array}$ & $\begin{array}{l}\text { n TBU }=\text { Total } \\
\text { la }\end{array}$ \\
\hline $\begin{array}{l}\text { 8. } \mathrm{TBU}=\mathrm{UG}+ \\
\text { BSP }\end{array}$ & $\mathrm{G}=\mathrm{Upah} /$ & & & & \\
\hline
\end{tabular}

\section{Aspek Pendapatan}

9. Pendapatan rumahtangga di PPLU 


\begin{tabular}{|c|c|c|c|c|c|}
\hline Peubah & Label & $\begin{array}{l}\text { Parameter } \\
\text { Dugaan }\end{array}$ & t-hitung & Prob> ltl & Elastisitas \\
\hline \multicolumn{6}{|l|}{ A. Aspek Produksi } \\
\hline \multicolumn{6}{|l|}{ luar usaha } \\
\hline Intercept & $\mathrm{a} 0$ & 1274918 & 0,69 & 0,4971 & \\
\hline Alokasi kerja di luar usaha & CKLU & 98267,08 & 15,22 & $<.0001$ & 0,848673 \\
\hline Angkatan kerja rumahtangga & $\mathrm{AKP}$ & 504088,7 & 1 & 0,323 & \\
\hline $\mathrm{R}^{2}=0,85199$ & \multicolumn{2}{|c|}{ Fvalue $=120,89$} & \multicolumn{3}{|c|}{$\operatorname{Pr}>\mathrm{F}=<, 00001$} \\
\hline $\begin{array}{l}\text { 10. PTP = PPD + } \\
\text { PPLU }\end{array}$ & \multicolumn{2}{|c|}{ PTP = Pendapatan Total Petani } & & & \\
\hline
\end{tabular}

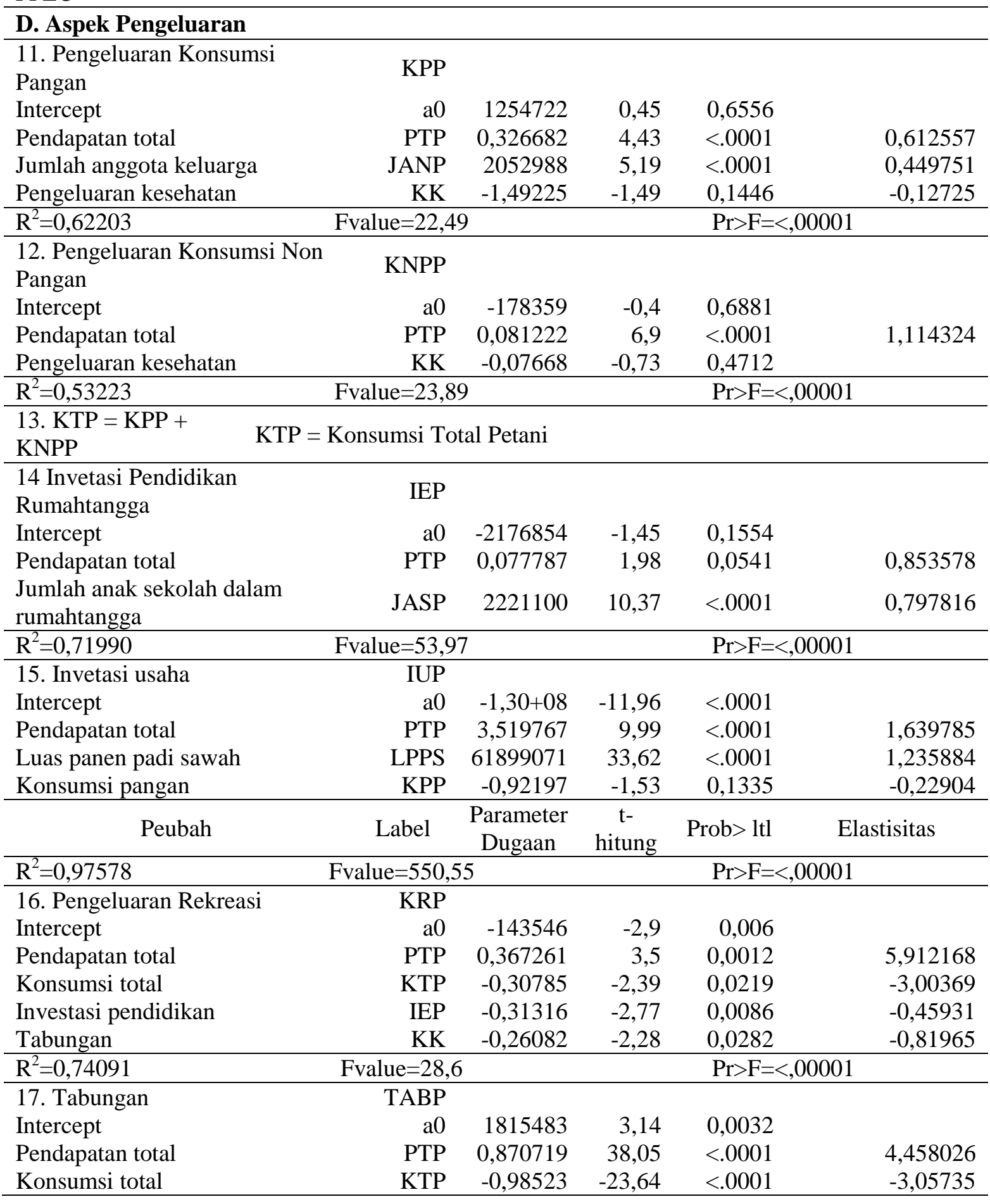




\begin{tabular}{lrrrrr}
\hline \multicolumn{1}{c}{ Peubah } & Label & $\begin{array}{c}\text { Parameter } \\
\text { Dugaan }\end{array}$ & t-hitung & Prob $>$ ltl & Elastisitas \\
\hline A. Aspek Produksi & & & & & \\
\hline Investasi pendidikan & IEP & $-0,93451$ & $-22,93$ & $<.0001$ & $-0,43593$ \\
Pengeluaran kesehatan & KK & $-0,9396$ & $-5,83$ & $<.0001$ & $-0,21878$ \\
\hline $\mathrm{R}^{2}=0,98939$ & Fvalue $=932,61$ & & & $\operatorname{Pr}>\mathrm{F}=<, 00001$ & \\
\hline
\end{tabular}

Tabel 2 dapat diterangkan bahwa peubah luas panen padi sawah (LPPS), total tenaga kerja dalam usahatani padi sawah (TTKU) dan biaya sarana produksi (BSP) berpengaruh positif terhadap aspek produksi (Q).Hanya saja, produksi tidak responsif dipengaruhi oleh semua variabel, hal ini dikarenakan menurunnya tingkat kesuburan tanah yang diusahakan petani serta makin tidak pastinya pola hujan akibat perubahan iklim global.

Aspek alokasi dan penggunan tenaga kerja dapat diterangkan bahwa pertama, faktor dominan yang mempengaruhi persamaan alokasi kerja dalam usahatani padi sawah (CKDU) adalah alokasi kerja luar usahatani padi sawah (CKLU) dan angkatan kerja rumahtangga petani (AKP).Namun, tidak ada peubah yang responsif mempengaruhi persamaan alokasi kerja dalam usahatani padi sawah.Kedua, persamaan penggunaan tenaga kerja luar keluarga petani (TKLP) responsif dipengaruhi peubah pendapatan di dalam usahatani padi sawah.Ketiga, pendapatan di luar usahatani padi sawah (PPLU), pengalaman kerja petani (PKP) bersifat postif, alokasi kerja dalam usahatani padi sawah (CKDU) dan umur petani (UP) bersifat negatif mempengaruhi persamaan alokasi kerja di luar usahatani padi sawah (CKLU). Namun, tidak ada peubah yang responsig mempengaruhi persamaan alokasi kerja luar usahatani padi sawah.

Aspek pendapatan luar usahatani padi sawah (PPLU) dipengaruhi secara positif oleh peubah alokasi kerja luar usahatani padi sawah.Hanya saja, alokasi kerja luar usahatani padi sawah tidak responsif mempengaruhi pendapatan luar usahatani padi sawah.

Aspek pengeluaran dapat diterangkan bahwa pertama, faktor dominan yang mempengaruhi persamaan pengaluaran konsumsi pangan (KPP) adalah pendapatan total (PTP), jumlah anggota keluarga (JANP) bersifat positif dan pengeluaran kesehatan (KK) bersifat negatif.Namun, semua peubah tidak responsif mempengaruhi persamaan pengeluaran konsumsi pangan.Kedua, persamaan konsumsi non pangan (KNPP) responsif dipengaruhi peubah pendapatan total.Ketiga, persamaan investasi pendidikan rumahtangga petani (IEP) dipengaruhi secara positif oleh peubah pendapatan total dan jumlah anak sekolah petani, namun kedua peubah tidak responsif mempengaruhi persamaan investasi pendidikan petani.Keempat, investasi pada usahatani padi sawah (IUP) memiliki faktor dominan pendapatan total, luas panen padi sawah yang bersifat positif dan pengeluaran konsumsi pangan bersifat negatif. Persamaan investasi pada usahatani padi sawah responsif dipengaruhi peubah pendapatan total dan luas panen padi sawah. Kelima, persamaan pengeluaran rekreasi (KRP) memiliki faktor dominan pendapatan total berisfat positif, konsumsi total, investasi pendidikan dan tabungan bersifat negatif. Persamaan pengeluaran rekreasi responsif dipengaruhi pendapatan total dan komsumsi total. Keenam, persamaan tabungan (TABP) memiliki faktor dominan pendapatan total bersifat positif, komsumsi total, investasi pendidikan dan pengeluaran rekreasi bersifat negatif. Persamaan tabungan responsif dipengaruhi peubah pendapatan total dan konsumsi total.

\section{KESIMPULAN DAN SARAN}

Berdasarkan hasil penelitian dan analisis maka dapat diambil kesimpulan sebagai berikut:

1. Tidak ada peubah yang responsif mempengaruhi produksi padi sawah.

2. Tidak ada peubah yang responsif mempengaruhi alokasi kerja dalam usahatani padi sawah dan alokasi kerja luar usahatani padi sawah.Penggunaan tenaga kerja luar keluarga dipengaruhi secara responsif oleh pendapatan rumahtangga dalam usahtani padi sawah. 
3. Tidak ada peubah yang responsif mempengaruhi pendapatan luar usahatani padi sawah.

4. idak ada peubah yang responsif mempengaruhi konsumsi pangan dan investasi pendidikan. Pengeluaran konsumsi non pangan responsif dipengaruhi oleh peubah pendapatan total rumahtangga petani padi sawah. Persamaan investasi pada usahatani padi sawah responsif dipengaruhi oleh peubah pendapatan total rumahtangga petani padi sawah dan luas panen padi sawah. Pengeluaran rekreasi dan tabungan responsif dipengaruhi peubah pendapatan total rumahtangga petani padi sawah dan konsumsi total rumahtangga petani padi sawah.

\section{DAFTAR PUSTAKA}

Badan Pusat Statistik Kabupaten Siak. 2015. Siak dalam Angka 2015. Badan Pusat Statistik Kabupaten Siak, Siak Sri Indrapura.

Becker, GS. 1965. A Theory of Allocation of Time. Economic Journal, 299 (75): 493517.

Chang, Y.M., Huang, B.W., \& Chen, Y.J.2012.Labor Supply, Income, and Welfareof the Farm Household. Labor Economics19 (2012) 427-437

Gujarati, D. 2011. Dasar-dasar Ekonometrika. Salemba Empat, Jakarta.
Intriligator, MD., 1978, Econometric Model, Techniques, and Applications. Prentice Hall Inc, New Jersey.

Kementerian Pertanian. 2015. Rencana Strategis Pembangunan Pertanian Tahun 2015-2019. Kementerian Pertanian, Republik Indonesia, Jakarta.

Koestiono, D. 2004. Analisis Ekonomi Rumahtangga dalam Usaha Konservasi (Kasus di Lahan Kering Jawa Timur Bagian Selatan): Disertasi. ProgramPascasarjana, Fakultas Pertanian, Universitas Brawijaya, Malang.

Koutsoyiannis, A. 1977.Theory of Econometrics.An Introductory Exspotion of Econometric Methods.Second Edition.Harper and Row Publisher Inc, New York.

Makki, M. F. 2014. Perilaku Ekonomi Rumahtangga Petani Padi di Lahan Rawa Lebak Kabupaten Hulu Sungai Utara Kalimantan Selatan : Disertasi. Program Pascasarjana Fakultas Pertanian Universitas Brawijaya, Malang

Pasari.bu, A. 1981. Pengantar Statistik. Ghalia Indonesia, Jakarta.

Pindyck, R.S and D.L. Rubinfield. 2000. Econometric Models and Economic Forecasts. McGraw-Hill Publishing Co, New York.

Suryana, A., S.Mardianto, dan M. Ikhsan. 2001. Dinamika Kebijakan Perberasan Nasional. Lembaga Penelitian Ekonomi Manajemen. Universitas Indonesia 